\title{
Antibiotic Exposure in Early Life Increases Risk of Childhood Obesity: A Systematic Review and Meta-Analysis
}

\author{
Xiaoqing Shao ${ }^{1 \dagger}$, Xiaolian Ding ${ }^{2 \dagger}$, Bin Wang ${ }^{1 \dagger}$, Ling $\mathrm{Li}^{1}$, Xiaofei An ${ }^{1}$, Qiuming Yao ${ }^{1}$, \\ Ronghua Song ${ }^{1}$ and Jin-an Zhang ${ }^{1 *}$
}

'Department of Endocrinology, Jinshan Hospital of Fudan University, Shanghai, China, ${ }^{2}$ Department of Nephrology and Endocrinology, Weinan Central Hospital, Weinan, China

\section{OPEN ACCESS}

Edited by:

Beverly Sara Muhlhausler, University of Adelaide, Australia

Reviewed by: Mark Vickers, University of Auckland, New Zealand

Kathleen Grace Mountjoy, University of Auckland, New Zealand

*Correspondence: Jin-an Zhang

zhangjinan@hotmail.com

tThese authors have contributed equally to this work.

Specialty section: This article was submitted to Obesity, a section of the journal Frontiers in Endocrinology

Received: 28 March 2017 Accepted: 03 July 2017 Published: 20 July 2017

Citation:

Shao $X$, Ding $X$, Wang B, Li L, An X, Yao $Q$, Song $R$ and Zhang J-a (2017) Antibiotic Exposure in Early Life Increases Risk of Childhood Obesity: A Systematic Review and Meta-Analysis.

Front. Endocrinol. 8:170. doi: 10.3389/fendo.2017.00170
A number of studies have previously assessed the impact of antibiotic exposure in early life on the risk of childhood obesity, but no systematic assessment is currently available. A systematic review and meta-analysis was performed to comprehensively and quantitatively elucidate the risk of childhood obesity caused by antibiotic exposure in early life. Literature search was performed in PubMed, Embase, and Web of Science. Random-effect meta-analysis was used to pool the statistical estimates. Fifteen cohort studies involving 445,880 participants were finally included, and all those studies were performed in developed countries. Antibiotic exposure in early life significantly increased risk of childhood overweight [relative risk $(R R)=1.23,95 \%$ confidence interval $(\mathrm{Cl})$ $1.13-1.35, P<0.001]$ and childhood obesity $(\mathrm{RR}=1.21,95 \% \mathrm{Cl} 1.13-1.30, P<0.001)$. Antibiotic exposure in early life also significantly increased the $z$-score of childhood body mass index (mean difference: $0.07,95 \% \mathrm{Cl} 0.05-0.09, P<0.00001$ ). Importantly, there was an obvious dose-response relationship between antibiotic exposure in early life and childhood adiposity, with a $7 \%$ increment in the risk of overweight $(R R=1.07,95 \%$ $\mathrm{Cl} 1.01-1.15, P=0.03)$ and a $6 \%$ increment in the risk of obesity $(R R=1.06,95 \% \mathrm{Cl}$ $1.02-1.09, P<0.001$ ) for each additional course of antibiotic exposure. In conclusion, antibiotic exposure in early life significantly increases risk of childhood obesity. Moreover, current analyses are mainly taken from developed countries, and therefore the impact of antibiotic exposure on risk of childhood obesity in vulnerable populations or developing countries still needs to be evaluated in future studies.

Keywords: antibiotics, childhood obesity, meta-analysis, risk factor, overweight

\section{INTRODUCTION}

Obesity has increased significantly among children and adolescents over the past several decades, and childhood adiposity has become a major challenge to public health worldwide $(1,2)$. In the United States, the prevalence of obesity in children and adolescents is about $17.0 \%$ and it has also increased substantially (3). Excess adiposity during childhood is likely to persist into adulthood and further increases the predisposition to cardiovascular diseases, cancer, and early mortality $(4,5)$. Childhood obesity also increases risk of other diseases during childhood, such as hypertension and depression (6-8). In addition, some obese children have exhibited early signs of cardiovascular dysfunction (9). The pathogenesis of obesity is complex and may involve many 
factors, and studies that explore the causes of the increasing epidemic of childhood obesity and possible solutions to this issue are necessary (10).

Emerging evidence has suggested that gut microbiota is linked to obesity and other metabolic disorders $(11,12)$. There are obvious changes in gut microbiota of patients with obesity, and these changes may precede the clinical manifestation of obesity (13). Antibiotics can result in obvious alterations in the gut microbiota and even gut dysbiosis, which may further result in obesity or other metabolic disorders $(12,14,15)$. Considering that antibiotics are frequently prescribed in pediatric patients, a precise assessment of the relationship between antibiotics and childhood obesity is very important (16). There are a number of epidemiological studies assessing the impact of antibiotic exposure in early life on childhood adiposity risk (17-24). Several studies reported that antibiotic exposure could increase the risk of childhood overweight or obesity $(17,19,23,24)$, while the other studies reported that antibiotic exposure had no obvious role on childhood adiposity risk $(18,21)$. Besides, no systematic review and meta-analysis is currently available that provides a definite evaluation of the relationship between antibiotic exposure and childhood adiposity. An improved understanding of the issue has important implications for public health, because there is an increasing epidemic of childhood obesity and prudent use of antibiotics in early life may be one way to reduce this epidemic. Therefore, a systematic review and meta-analysis of available studies was performed to assess the relationship between antibiotic exposure in early life and childhood adiposity.

\section{MATERIALS AND METHODS}

\section{Literature Search}

A literature search in PubMed, Emabse, and Web of Science was carried out to find articles that examined the impact of antibiotic exposure on childhood adiposity risk. The following terms were used: (antibiotics OR antibiotic OR tetracycline OR doxycycline OR cephalosporin OR penicillin OR metronidazole OR fluoroquinolone OR sulfonamide OR macrolide) AND (adiposity OR obesity OR obese OR overweight OR body mass index) AND (child OR children OR childhood OR boy* OR girl* OR infancy OR infants). All databases were searched from their inception through September 6, 2016, and an updated literature search was performed on February 26, 2017. Language restriction was not applied. Bibliographies of eligible articles and relevant reviews were also screened.

\section{Selection Criteria}

Selection criteria for the meta-analysis were as following: (1) prospective or retrospective cohort studies; (2) the outcomes of interest were the association between antibiotic exposure and childhood adiposity, or the impact of antibiotic exposure on childhood body mass index (BMI) or weight; (3) the exposure time was early life including infancy and prenatal period; (4) reporting risk estimates on the associations, such as relative risks (RRs) with 95\% confidence intervals (95\% CIs), or the difference in the $z$-scores of childhood BMI or weight between the exposed group and the non-exposed group. Infancy is usually defined as the period from birth to 2 years of age. Early life includes infancy and prenatal period, and is thus from fetal life through 2 years of age in the present study. Studies containing overlapping data, case reports, or case series were all excluded.

\section{Data Extraction and Quality Evaluation}

Two colleagues extracted data independently, and discrepancy was resolved by discussion. The extracted data mainly included first author, country, study design, antibiotic exposure, participants, follow-up time, adjusted variables, and outcomes of interest. If one study reported data of multiple follow-ups, we used the data for the longest follow-up time. The authors of included studies were contacted if crucial information was not provided in the articles.

The primary outcome of interest was the association of antibiotic exposure in early life with childhood overweight or obesity. The secondary outcome of interest was the difference of the $z$-scores of childhood BMI or weight between the exposed group and the non-exposed group. The evaluation of study quality was performed by the Newcastle-Ottawa scale, and studies scoring seven or more points were identified as high-quality studies (25).

\section{Data Analysis}

The risk estimates on the associations between antibiotic exposure and childhood adiposity and the differences of childhood body weight between the exposed group and the non-exposed group were pooled using meta-analysis. Heterogeneity was measured using Cochran-Q test and $I^{2}$ method $(26,27)$. Random-effect

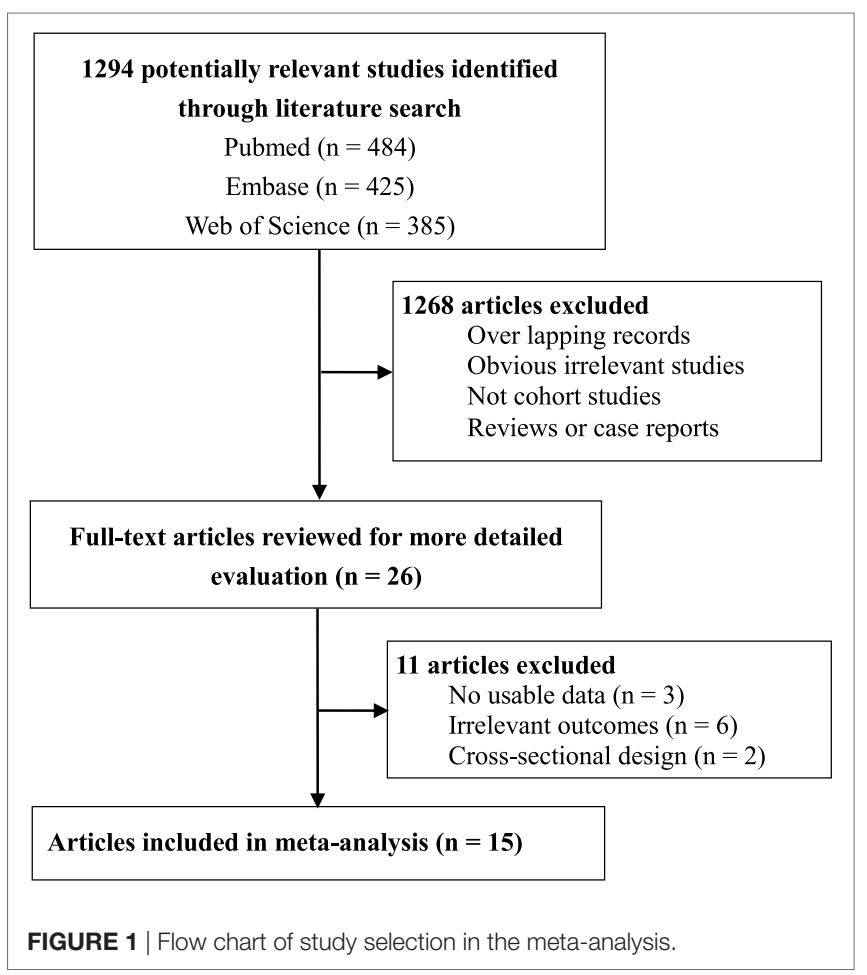


TABLE 1 | Characteristics of those 15 cohort studies on the association between antibiotic exposure in early life and risk of childhood adiposity.

\begin{tabular}{|c|c|c|c|c|c|c|c|c|}
\hline Study & $\begin{array}{l}\text { Location } \\
\text { (baseline time) }\end{array}$ & Study design & Participants & Exposure time & $\begin{array}{l}\text { Time of } \\
\text { follow-up }\end{array}$ & Outcomes & Adjustment & Quality ${ }^{a}$ \\
\hline Ajslev et al. (17) & $\begin{array}{l}\text { Denmark } \\
(1997-2002)\end{array}$ & $\begin{array}{l}\text { Prospective } \\
\text { cohort }\end{array}$ & $\begin{array}{l}28,354 \text { children } \\
\text { dyads from the Danish } \\
\text { National Birth Cohort }\end{array}$ & $\begin{array}{l}\text { Infancy } \\
\text { (<6 months) }\end{array}$ & 7 years & Overweight & $\begin{array}{l}\text { Maternal age, socioeconomic status, prepregnancy BMI, gestational weight } \\
\text { gain, smoking, paternal BMl, parity, birth weight, sex, breastfeeding, and } \\
\text { age at } 7 \text {-year follow-up }\end{array}$ & 9 \\
\hline $\begin{array}{l}\text { Halldorsson } \\
\text { et al. (33) }\end{array}$ & $\begin{array}{l}\text { Denmark } \\
(1988-1989)\end{array}$ & $\begin{array}{l}\text { Prospective } \\
\text { cohort }\end{array}$ & $\begin{array}{l}665 \text { pregnant women } \\
\text { with offspring }\end{array}$ & Prenatal & 20 years & Overweight & $\begin{array}{l}\text { Maternal age, maternal education, maternal prepregnancy BMI, smoking } \\
\text { during pregnancy, parity, infant birth weight, and offspring age at follow-up }\end{array}$ & 8 \\
\hline Murphy et al. (18) & $\begin{array}{l}\text { New Zealand } \\
(1995-1996)\end{array}$ & $\begin{array}{l}\text { Prospective } \\
\text { cohort }\end{array}$ & 871 European children & $\begin{array}{l}\text { Infancy } \\
\text { (<12 months) }\end{array}$ & 11 years & BMl z-score & Maternal smoking and breastfeeding & 7 \\
\hline $\begin{array}{l}\text { Trasande } \\
\text { et al. (23) }\end{array}$ & $\begin{array}{l}\text { UK } \\
(1991-1992)\end{array}$ & $\begin{array}{l}\text { Prospective } \\
\text { cohort }\end{array}$ & 11,532 children & $\begin{array}{l}\text { Infancy } \\
\text { (<6 months) }\end{array}$ & 7 years & $\begin{array}{l}\text { Overweight, } \\
\text { obesity, BMl } \\
z \text {-score }\end{array}$ & $\begin{array}{l}\text { Birth weight, maternal parity, race, social class, education, parental BMI, first trimester } \\
\text { smoking, breastfeeding, timing of introduction of complementary foods, time spent per } \\
\text { day watching television, in car on weekdays, in car on weekends, dietary pattern } \\
\text { classifications at } 38 \text { months, and duration of nighttime sleep at } 7 \text { years }\end{array}$ & 9 \\
\hline Bailey et al. (19) & $\begin{array}{l}\text { USA } \\
(2001-2009)\end{array}$ & $\begin{array}{l}\text { Prospective } \\
\text { cohort }\end{array}$ & 64,580 children & $\begin{array}{l}\text { Infancy } \\
\text { (<24 months) }\end{array}$ & 5 years & Obesity & $\begin{array}{l}\text { Steroid use, gender, age, urban practice, public insurance, primary care visits, } \\
\text { Hispanic ethnicity, diagnosed asthma or wheezing, calendar year of first visit, } \\
\text { antireflux medication use, and common infectious diagnoses. }\end{array}$ & 9 \\
\hline Azad et al. (24) & $\begin{array}{l}\text { Canada } \\
\text { (1995) }\end{array}$ & $\begin{array}{l}\text { Prospective } \\
\text { cohort }\end{array}$ & 616 children & $\begin{array}{l}\text { Infancy } \\
\text { (<12 months) }\end{array}$ & 9 years & Overweight & $\begin{array}{l}\text { Birth weight, breastfeeding, smoke exposure at birth, family income, sibship, diet, } \\
\text { physical activity at age } 9 \text {, current asthma, maternal asthma, and maternal overweight }\end{array}$ & 8 \\
\hline Saari et al. (41) & $\begin{array}{l}\text { Finland } \\
(2003-2007)\end{array}$ & $\begin{array}{l}\text { Prospective } \\
\text { cohort }\end{array}$ & $\begin{array}{l}6,114 \text { healthy } \\
\text { boys and } 5,948 \\
\text { healthy girls }\end{array}$ & $\begin{array}{l}\text { Infancy } \\
(<24 \text { months })\end{array}$ & $\begin{array}{l}\text { More than } \\
2 \text { years }\end{array}$ & $\begin{array}{l}\text { Overweight, } \\
\text { BMl z-score }\end{array}$ & $\begin{array}{l}\text { Maternal smoking after the first trimester, parental relationship, mode of delivery, } \\
\text { birth weight, and birth length }\end{array}$ & 9 \\
\hline Mueller et al. (20) & $\begin{array}{l}\text { USA } \\
(1998-2006)\end{array}$ & $\begin{array}{l}\text { Prospective } \\
\text { cohort }\end{array}$ & 436 children & Prenatal & 7 years & $\begin{array}{l}\text { Obesity, BMl } \\
z \text {-score }\end{array}$ & $\begin{array}{l}\text { Maternal age, ethnicity, pregravid BMI, maternal receipt of public assistance, birth } \\
\text { weight, sex, breast feeding in the first year, and gestational antibiotics or delivery model }\end{array}$ & 7 \\
\hline Mor et al. (39) & $\begin{array}{l}\text { Denmark } \\
(1994-1998)\end{array}$ & $\begin{array}{l}\text { Prospective } \\
\text { cohort }\end{array}$ & 9,886 school children & Prenatal & 14.5 years & $\begin{array}{l}\text { Overweight, } \\
\text { obesity }\end{array}$ & $\begin{array}{l}\text { Maternal age at delivery, marital status, smoking in pregnancy multiple gestation, } \\
\text { and birth weight }\end{array}$ & 8 \\
\hline Scott et al. (45) & $\begin{array}{l}\text { UK } \\
(1995-2003)\end{array}$ & $\begin{array}{l}\text { Retrospective } \\
\text { cohort }\end{array}$ & $\begin{array}{l}1,714 \text { children in The } \\
\text { Health Improvement } \\
\text { Network }\end{array}$ & $\begin{array}{l}\text { Infancy } \\
(<24 \text { months })\end{array}$ & 4 years & $\begin{array}{l}\text { Obesity, BMl } \\
z \text {-score }\end{array}$ & $\begin{array}{l}\text { Year of birth, maternal and sibling obesity, maternal diabetes, mode of delivery, } \\
\text { country of origin, urban environment, and Townsend score }\end{array}$ & 8 \\
\hline $\begin{array}{l}\text { Mbakwa } \\
\text { et al. (22) }\end{array}$ & $\begin{array}{l}\text { Netherlands } \\
\text { (2000-2002) }\end{array}$ & $\begin{array}{l}\text { Prospective } \\
\text { cohort }\end{array}$ & 979 children & $\begin{array}{l}\text { Infancy } \\
\text { (<24 months) }\end{array}$ & 9 years & $\begin{array}{l}\text { Overweight, } \\
\text { weight } \\
z \text {-score, BMl } \\
z \text {-score }\end{array}$ & $\begin{array}{l}\text { Recruitment group, household size, maternal level of education, maternal } \\
\text { prepregnancy weight, maternal pregnancy weight gain, smoking during pregnancy, } \\
\text { gestational diabetes, gestational hypertension, place, and mode of delivery, sex, } \\
\text { birth weight, gestational age, duration of breastfeeding, dietary intake, child's } \\
\text { physical activity, and child's ages during anthropometric measurements }\end{array}$ & 8 \\
\hline Gerber et al. (21) & $\begin{array}{l}\text { USA } \\
(2001-2011)\end{array}$ & $\begin{array}{l}\text { Retrospective } \\
\text { cohort }\end{array}$ & 44,737 children & $\begin{array}{l}\text { Infancy } \\
\text { (<6 months) }\end{array}$ & 5 years & $\begin{array}{l}\text { Weight } \\
z \text {-score }\end{array}$ & $\begin{array}{l}\text { Sex, birth weight, race, Medicaid insurance status, number of siblings, birth year, } \\
\text { baseline length, and primary care site }\end{array}$ & 9 \\
\hline Li et al. (29) & $\begin{array}{l}\text { USA } \\
(1997-2013)\end{array}$ & $\begin{array}{l}\text { Retrospective } \\
\text { cohort }\end{array}$ & 260,556 children & $\begin{array}{l}\text { Infancy } \\
\text { ( }<12 \text { months) }\end{array}$ & 9 years & Obesity & $\begin{array}{l}\text { Maternal age, race or ethnic origin, prepregnancy BMl, preterm delivery, low birth } \\
\text { weight, maternal antibiotic use, and infection during pregnancy }\end{array}$ & 9 \\
\hline Poulsen et al. (49) & $\begin{array}{l}\text { USA } \\
(2006-2012)\end{array}$ & $\begin{array}{l}\text { Retrospective } \\
\text { cohort }\end{array}$ & $\begin{array}{l}8,793 \text { singleton } \\
\text { children }\end{array}$ & $\begin{array}{l}\text { Prenatal; infancy } \\
\text { (<12 months) }\end{array}$ & 3 years & BMl z-score & $\begin{array}{l}\text { Centered child exact age, mother race/ethnicity, cesarean section, birth weight, } \\
\text { mother Medical Assistance, smoked during pregnancy, parity, and pregravid BMl }\end{array}$ & 8 \\
\hline Ville et al. (48) & $\begin{array}{l}\text { USA } \\
(2012-2013)\end{array}$ & $\begin{array}{l}\text { Prospective } \\
\text { cohort }\end{array}$ & 97 Latino children & $\begin{array}{l}\text { Infancy } \\
\text { (<6 months) }\end{array}$ & 2 years & Obesity & Maternal BMI, birth weight, breastfeeding, infant weight gain, and infant sex & 7 \\
\hline
\end{tabular}

${ }^{a}$ Quality was assessed using NOS method. 
model was utilized to pool data in order to reduce the impact of heterogeneity across studies (28). Subgroup analyses were carried out by gender, exposure time, and study design. The study by
Li et al. (29) reported data from two different comparisons, and we firstly used the risk estimate from the comparison between infants who used antibiotics and those who did not, and then

\section{A}

Study

$\operatorname{RR}(95 \% \mathrm{Cl}) \quad$ Weight

ID

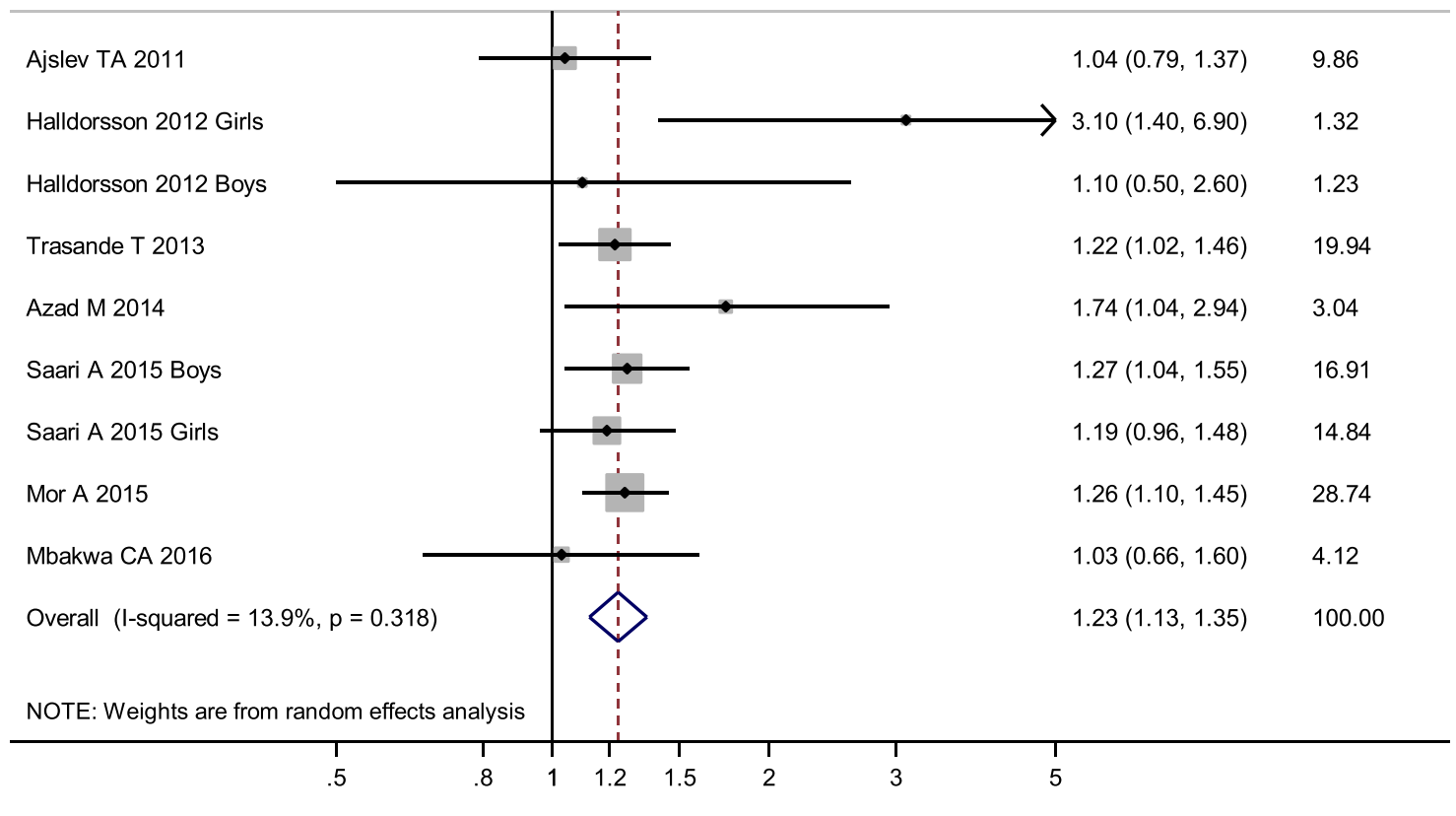

Study

$\%$

ID

$\mathrm{RR}(95 \% \mathrm{Cl}) \quad$ Weight

Trasande L 2013

Bailey LC 2014

Mueller NT 2015

Mor A 2015

Scott FI 2016

Li DK 2016

Ville A 2017

Overall $(\mathrm{I}$-squared $=46.8 \%, p=0.080)$

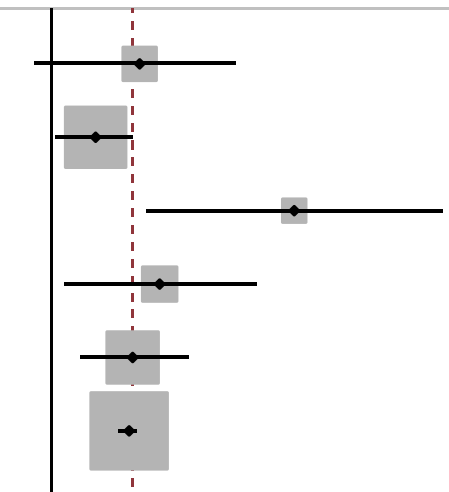

$1.23(0.96,1.54) \quad 7.30$

$1.11(1.01,1.21) \quad 24.35$

$1.77(1.25,2.51) \quad 3.71$

$1.29(1.03,1.62) \quad 7.82$

$1.21(1.07,1.38) \quad 17.48$

$1.20(1.17,1.22) \quad 39.19$

$6.15(1.03,36.70) \quad 0.16$

$1.21(1.13,1.30) \quad 100.00$

NOTE: Weights are from random effects analysis

.5


1.2

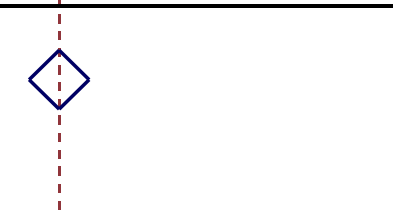

FIGURE 2 | Continued 


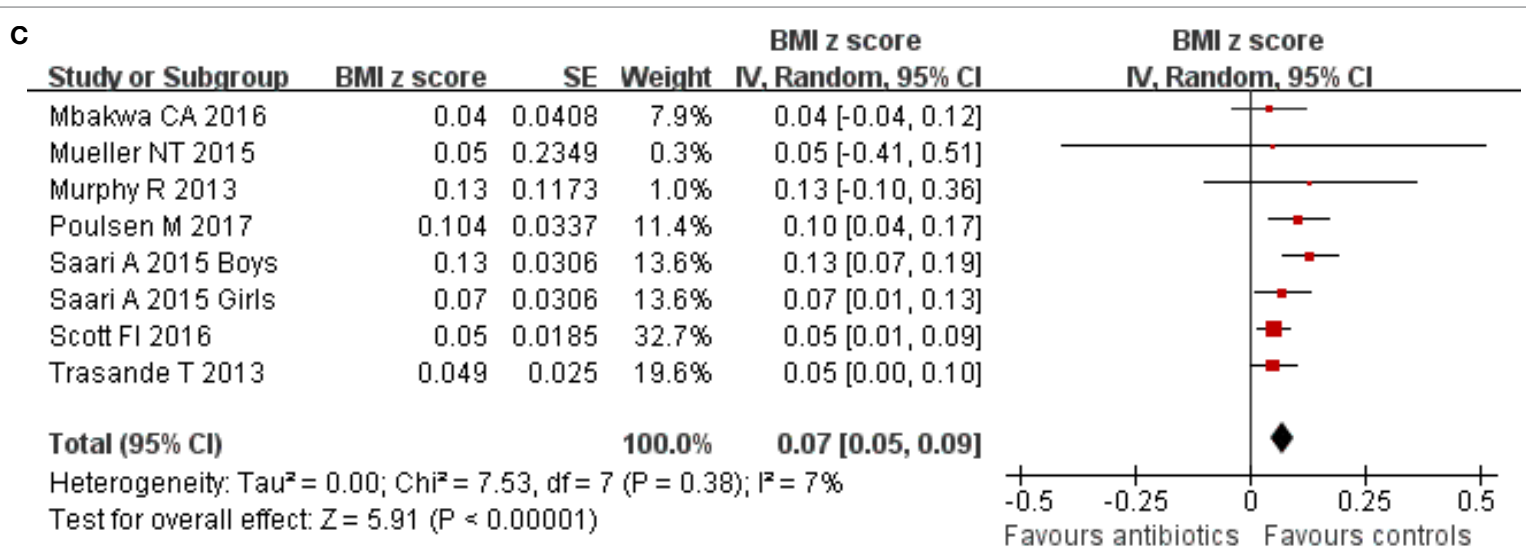

FIGURE 2 | Meta-analysis suggested that antibiotic exposure in early life increased risk of childhood adiposity. (A) Meta-analysis of studies on childhood overweight risk associated with antibiotic exposure in early life. (B) Meta-analysis of studies on childhood obesity risk associated with antibiotic exposure in early life.

(C) Meta-analysis of studies on changes of body mass index z-scores associated with antibiotic exposure in early life.

performed a sensitivity analysis by using the risk estimate from the comparison between infants who used antibiotics and those who had infections but did not receive antibiotics. Publication bias was evaluated by Egger's test and funnel plot (30). For doseresponse meta-analysis, the correlated log RR estimates across different courses of antibiotic exposure were calculated using generalized least-square regression method, and RRs were further pooled using random-effect meta-analysis $(31,32)$. STATA (version 12.0) and Review Manager (version 5.2) were used for statistical analyses. $P<0.05$ indicated a statistically significant difference.

\section{RESULTS}

\section{Study Selection and Characteristics}

From the literature search, we found a total of 1,294 abstracts, but only 26 studies were considered as potentially eligible and assessed by reading full-texts (17-24, 29, 33-49) (Figure 1). After detailed evaluation, 11 studies were further removed including 6 studies for irrelevant outcomes (34-36, 40, 42, 47), 3 studies for no usable data $(38,43,44)$, and 2 studies for crosssectional design $(37,46)$. The study by Korpela et al. only reported the $r$-value from linear correlation analysis, but did not report the difference in the $z$-score of childhood BMI or weight (43). Ultimately, 15 cohort studies involving 445,880 participants were included (17-24, 29, 33, 39, 41, 45, 48, 49) (Figure 1). Table 1 showed the characteristics of those 15 cohort studies (Table 1). There were 12 prospective cohort studies, and 3 retrospective cohort studies (Table 1). Those studies were published from 2011 to 2017. There was an obvious difference in the number of participants, which ranged from 97 to 260,556. All studies were performed in developed countries, and no study was from developing countries or was performed in predefined vulnerable populations (Table 1). Besides, about $40 \%$ of the studies were in the United States and represented over $75 \%$ of all subjects (Table 1).
Among those 15 studies, 7 studies assessed the relationship between antibiotic exposure and childhood overweight (17, 22-24, $33,39,41)$, 7 studies assessed the relationship between antibiotic exposure and childhood obesity $(19,20,23,29,39,45,48), 7$ studies analyzed the influence of antibiotic exposure on childhood BMI (18, 20, 22, 23, 41, 45, 49), and 2 studies assessed the influence of antibiotic exposure on childhood body weight $(21,22)$ (Table 1). Twelve studies assessed the relationship between antibiotic exposure during infancy and childhood adiposity, and four studies examined the impact of prenatal antibiotic exposure on childhood adiposity (Table 1). Six studies reported data for the dose-response meta-analysis (19, 22, 24, 39, 41, 45). All studies reported adjusted risk estimates, but the confounding factors were different (Table 1). The quality of included studies was shown in Table 1.

\section{Meta-Analysis}

No obvious heterogeneity existed in those studies relating antibiotic exposure and childhood overweight $\left(I^{2}=13.9 \%\right)$. Meta-analysis showed that antibiotic exposure in early life (from fetal life through age 2) significantly increased the risk of childhood overweight $(\mathrm{RR}=1.23,95 \%$ CI $1.13-1.35, P<0.001)$ (Figure 2A). Subgroup analysis by exposure time suggested that both antibiotic exposure during infancy (from birth through age 2) and prenatal exposure to antibiotics could increase risk of childhood overweight (Table 2). Other subgroup analyses by gender and time of antibiotic exposure during infancy also found increased risk of childhood overweight among those children with antibiotic exposure in early life (Table 2).

There was moderate heterogeneity among studies relating antibiotic exposure and childhood obesity $\left(I^{2}=46.8 \%\right)$. Metaanalysis showed that antibiotic exposure in early life (from fetal life through age 2) also independently increased childhood obesity risk $(\mathrm{RR}=1.21,95 \% \mathrm{CI} 1.13-1.30, P<0.001)$ (Figure $2 \mathrm{~B}$ ). When using the risk estimate of the comparison between infants who used antibiotics and those who had infections but did not 
TABLE 2 | Meta-analysis of the association between antibiotic exposure in early life and risk of childhood adiposity.

\begin{tabular}{|c|c|c|c|c|}
\hline Outcomes & $\begin{array}{c}\text { Study } \\
\text { (participants) }\end{array}$ & $\begin{array}{c}\text { Pooled } \\
\text { estimates } \\
(95 \% \mathrm{Cl})\end{array}$ & $P$-value & $I^{2}(\%$ \\
\hline \multicolumn{5}{|l|}{ Overweight } \\
\hline Total studies & $7(64,096)$ & $1.23(1.13-1.35)$ & $<0.001$ & 13.9 \\
\hline $\begin{array}{l}\text { Prospective cohort } \\
\text { studies }\end{array}$ & $7(64,096)$ & $1.23(1.13-1.35)$ & $<0.001$ & 13.9 \\
\hline Exposure during infancy & $5(53,545)$ & $1.21(1.09-1.33)$ & $<0.001$ & 0 \\
\hline Prenatal exposure & $2(10,551)$ & $1.27(1.11-1.45)$ & 0.001 & 0 \\
\hline $\begin{array}{l}\text { Exposure during infancy } \\
\text { (<6 months) }\end{array}$ & $5(53,545)$ & $1.22(1.09-1.36)$ & $<0.001$ & 0 \\
\hline $\begin{array}{l}\text { Exposure during infancy } \\
\text { (6-12 months) }\end{array}$ & $3(13,659)$ & $1.25(1.10-1.42)$ & 0.001 & 0 \\
\hline $\begin{array}{l}\text { Exposure during infancy } \\
\text { (12-24 months) }\end{array}$ & $2(13,043)$ & $1.20(1.01-1.43)$ & 0.042 & 0 \\
\hline Boys & $4(23,231)$ & $1.48(1.16-1.88)$ & 0.001 & 51.4 \\
\hline Girls & $4(23,231)$ & $1.17(1.02-1.35)$ & 0.029 & 0 \\
\hline \multicolumn{5}{|l|}{ Obesity } \\
\hline Total studies & $7(348,801)$ & $1.21(1.13-1.30)$ & $<0.001$ & 46.8 \\
\hline $\begin{array}{l}\text { Prospective cohort } \\
\text { studies }\end{array}$ & $5(86,521)$ & $1.30(1.08-1.56)$ & 0.007 & 63.4 \\
\hline $\begin{array}{l}\text { Retrospective cohort } \\
\text { studies }\end{array}$ & $2(262,270)$ & $1.20(1.18-1.23)$ & $<0.001$ & 0 \\
\hline Exposure during infancy & $5(338,479)$ & $1.18(1.12-1.25)$ & $<0.001$ & 33.7 \\
\hline Prenatal exposure & $2(10,322)$ & $1.47(1.08-1.99)$ & 0.014 & 55.1 \\
\hline $\begin{array}{l}\text { Exposure during infancy } \\
\text { (<6 months) }\end{array}$ & $5(338,479)$ & $1.15(1.04-1.26)$ & 0.005 & 67.0 \\
\hline $\begin{array}{l}\text { Exposure during infancy } \\
\text { (6-12 months) }\end{array}$ & $3(326,850)$ & $1.07(0.95-1.22)$ & 0.269 & 83.9 \\
\hline $\begin{array}{l}\text { Exposure during infancy } \\
\text { (12-24 months) }\end{array}$ & $2(66,294)$ & $1.06(0.96-1.16)$ & 0.259 & $0 \%$ \\
\hline Boys & $1(9,886)$ & $1.29(0.96-1.73)$ & 0.09 & NA \\
\hline Girls & $1(9,886)$ & $1.27(0.89-1.82)$ & 0.19 & NA \\
\hline \multicolumn{5}{|l|}{ BMI z-score } \\
\hline Total studies & $7(36,389)$ & $0.07(0.05-0.09)$ & $<0.00001$ & 7 \\
\hline $\begin{array}{l}\text { Prospective cohort } \\
\text { studies }\end{array}$ & $5(25,882)$ & $0.07(0.04-0.10)$ & $<0.00001$ & 6 \\
\hline $\begin{array}{l}\text { Retrospective cohort } \\
\text { studies }\end{array}$ & $2(10,507)$ & $0.07(0.02-0.12)$ & 0.008 & $53 \%$ \\
\hline Exposure during infancy & $6(35,953)$ & $0.07(0.05-0.10)$ & $<0.00001$ & 20 \\
\hline Boys & $1(12,064)$ & $0.13(0.07-0.19)$ & $<0.0001$ & NA \\
\hline Girls & $1(12,064)$ & $0.07(0.01-0.13)$ & 0.02 & NA \\
\hline \multicolumn{5}{|l|}{ Weight z-score } \\
\hline Total studies & $2(45,716)$ & $0.06(0.01-0.11)$ & 0.03 & 0 \\
\hline
\end{tabular}

NA, not available.

receive antibiotics in the study by $\mathrm{Li}$ et al. (29), antibiotic exposure in early life still increased childhood obesity risk $(\mathrm{RR}=1.18$, 95\% CI $1.05-1.32, P=0.005)$. Subgroup analysis by exposure time suggested that antibiotic exposure during either infancy or prenatal period both increased childhood obesity risk (Table 2; Figure 3).

No heterogeneity existed in those studies relating antibiotic exposure and childhood BMI $z$-score $(18,20,22,23,41$, $45,49)\left(I^{2}=7 \%\right)$. Meta-analysis showed that antibiotic exposure in early life could dramatically increase the $z$-score of childhood BMI (mean difference: 0.07, 95\% CI 0.05-0.09, $P<0.00001$ ) (Figure 2C). Antibiotic exposure could markedly increase the $z$-score of childhood BMI in both boys and girls (Table 2; Figure 3).
Meta-analysis of two studies $(21,22)$ relating antibiotic exposure during infancy and childhood weight showed that antibiotic exposure could significantly increase the $z$-score of childhood weight (mean difference: $0.06,95 \%$ CI 0.01-0.11, $\left.P=0.03 ; I^{2}=0 \%\right)$.

The funnel plot did not show an obvious risk of publication bias (Figure 4). $P_{\text {Eggers test }}$ was 0.99 and it also proved the lack of publication bias. In addition, funnel plots in other meta-analyses on childhood obesity or childhood BMI also did not show an obvious risk of publication bias.

\section{Dose-Response Meta-Analysis}

Dose-response meta-analysis of six studies (19, 22, 24, 39, 41, 45) showed that there was an obvious dose-response relationship between antibiotic exposure and childhood adiposity, with a 7\% increment in the risk of childhood overweight (per one course $\mathrm{RR}=1.07,95 \% \mathrm{CI} 1.01-1.15, P=0.03)$ and a $6 \%$ increment in the risk of childhood obesity (per one course $R R=1.06,95 \%$ CI 1.02-1.09, $P<0.001)$ for each additional course of antibiotic exposure (Figures 5A,B).

\section{DISCUSSION}

The present study is the first systematic review comprehensively evaluating the impact of antibiotic exposure on childhood adiposity. Fifteen cohort studies involving 445,880 participants were finally included $(17-24,29,33,39,41,45,48,49)$. The results suggested that antibiotic exposure during early life significantly increased risk of childhood overweight and obesity, and there was an obvious dose-dependent relationship. In addition, antibiotic exposure also significantly increased the $z$-scores of childhood BMI and body weight. Thus, the meta-analysis provides strong evidence for the impact of antibiotic exposure during early life on childhood adiposity risk.

Another important issue is whether antibiotic exposure is an independent risk factor for childhood adiposity. In present metaanalysis, all included studies provided risk estimates adjusted for confounding factors (Table 1). The pooled adjusted RRs for the associations of antibiotic exposure during early life with childhood overweight and obesity were both statistically significant (Table 2). In addition, the $z$-scores of childhood BMI or body weight from included studies were also adjusted for confounding factors, and the pooled $z$-scores were statistically significant (Table 2). Therefore, this meta-analysis proves that antibiotic exposure is an independent risk factor of childhood obesity.

The pathogenesis of obesity is complex and has not been well understood, and it is the same with childhood obesity $(50,51)$. The role of gut microbiota in the pathogenesis of obesity is increasingly recognized, and accumulating evidence has suggested that gut microbiota has a causal role in obesity $(50,52,53)$. Ussar et al. proposed that obesity was a result of interactions between gut microbiota, host genetics, and diet (54). However, the molecular mechanisms underlying the role of gut microbiota in obesity are not yet well known (55). More studies are still needed to further characterize the molecular mechanism of gut microbiota in modulating energy balance and obesity (56). Exploring the role of gut microbiota in childhood obesity 


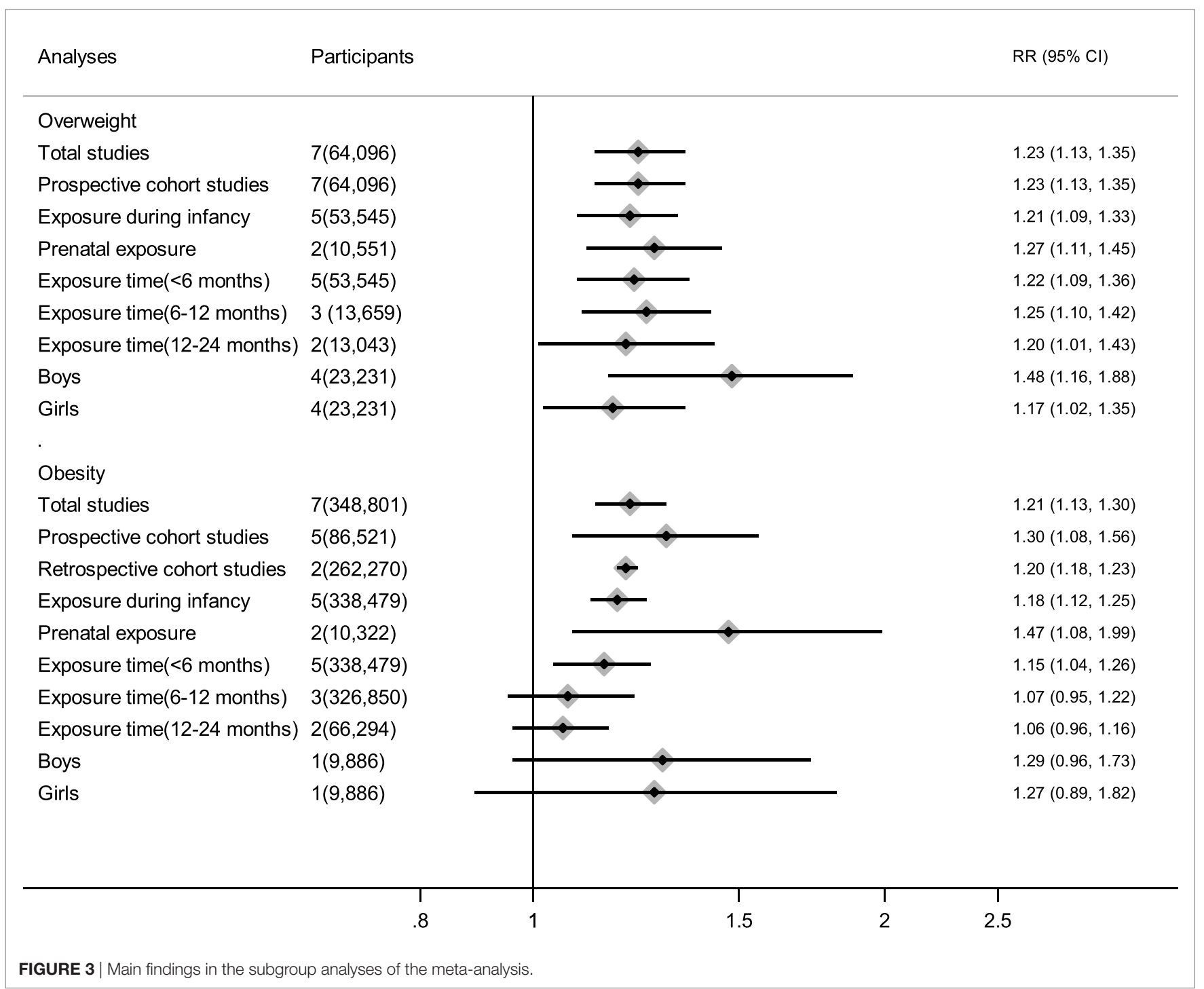

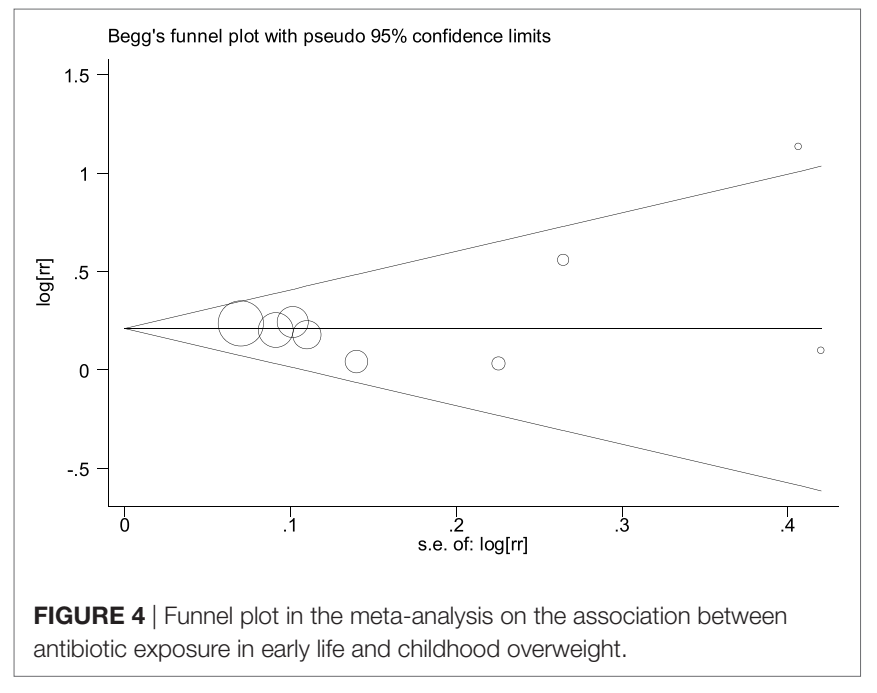

may also provide effective prevention or treatment strategies for childhood obesity (57). For example, a recent randomized controlled trial by Nicolucci et al. reported that probiotics can improve the eco-system imbalance of gut microbiotia and reduce the BMI $z$-score in children with overweight or obesity (58).

Data from animal studies have shown that antibiotic-induced changes in gut microbiota can result in fat accumulation by changing host metabolism (59). Antibiotics can also increase insulin resistance by changing gut microbiota $(60,61)$. Cho et al. reported that antibiotics could alter the murine colonic microbiome and result in the development of obesity (62). Therefore, the important roles of gut microbiota in modulating energy balance and the alerted composition of gut microbiota caused by antibiotics provide some explanations for the association between antibiotic exposure and childhood adiposity. However, more researches are still needed to further explore the complex mechanism underlying this association. 


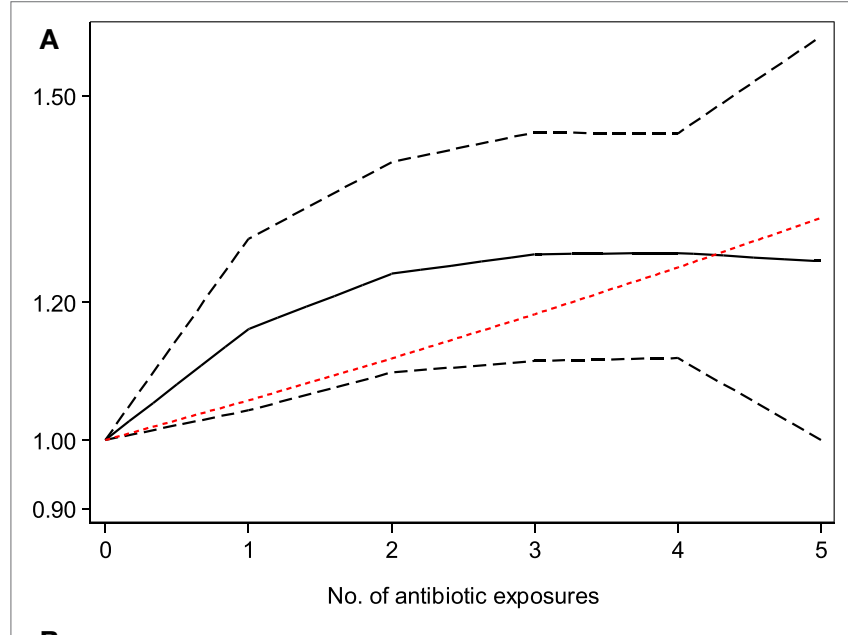

B

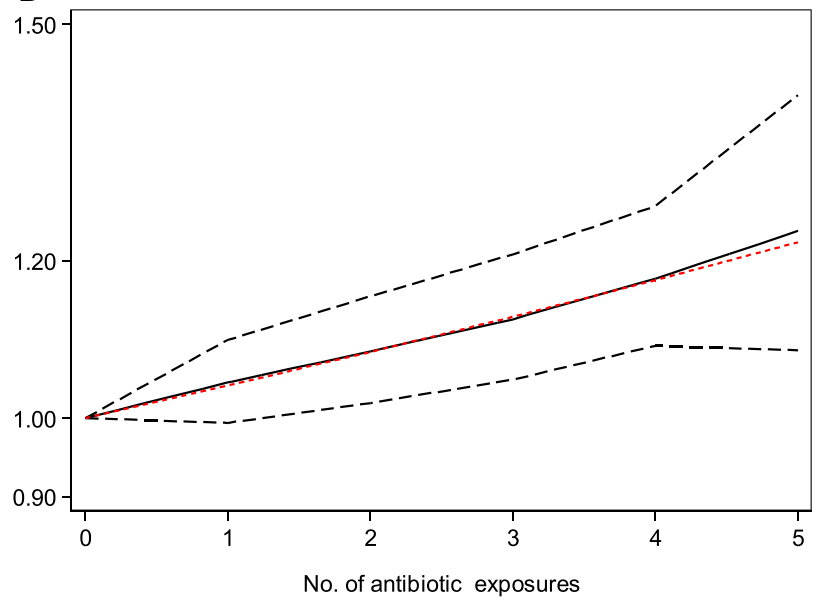

FIGURE 5 | Dose-response meta-analysis of the association between antibiotic exposure in early life and childhood adiposity (the solid black line and the short dash black line represent the estimated relative risk and corresponding 95\% confidence intervals of the non-linear relationship; long dash red line represents the linear relationship). (A) Dose-response meta-analysis of the association between antibiotic exposure in early life and childhood overweight. (B) Dose-response meta-analysis of the association between antibiotic exposure in early life and childhood obesity.

The increasing prevalence of childhood adiposity has become a major global health challenge, and actions to reduce the prevalence of obesity in children and adolescents are urgently needed $(4,63,64)$. Investigating risk factors associated with childhood obesity can help us to develop effective prevention interventions (65). The meta-analysis suggests that antibiotic exposure can result in a substantially increased risk of childhood obesity. The finding has important implications in the clinical setting, since antibiotics are the most common drugs administered in infants. Clinicians should weigh the risk of subsequent childhood obesity associated with antibiotic exposure in early life when considering antibiotics in the absence of a clear indication. The meta-analysis also indicates that prudent use of antibiotics may help to minimize the metabolic consequences of antibiotic exposure in early life. In addition, the approach that uses population analyses to understand pharmacokinetic/pharmacodynamic
(PK/PD) parameters in children exposed to antibiotics is helpful to define optimal antibiotic dose and course duration, which undoubtedly can improve clinical outcomes and patient safety (66). To assess the impact of antibiotic exposure in early life on childhood obesity more adequately, population PK/PD analyses exploring the impact of antibiotics in different doses and course duration on body composition in children are recommended in future research.

Apart from the prudent use of antibiotics in infants, it is also important for us to develop some plausible methods to prevent obesity in those infants or children who have to receive the treatment of antibiotics. Several studies have studied some possible ways to prevent obesity in children who expose to antibiotics. Kaliannan et al. demonstrated a beneficial effect of omega-3 fatty acid in preventing antibiotic-induced gut dysbiosis and obesity (67). Economopoulos et al. found that co-administration of intestinal alkaline phosphatase with azithromycin prevented the development of metabolic diseases in mice, and the effect was mediated by alterations in gut microbiota (68). However, more studies are still needed to develop some effective methods to prevent the antibiotics-induced obesity in infants or children exposing to antibiotics.

The meta-analysis had several strengths. Firstly, the large number of participants could provide a precise evaluation of the relationship between antibiotics and childhood adiposity. In addition, the obvious dose-dependent relationship strengthened the evidence for the association. Finally, the consistency in the findings of several different types of outcomes further supported the robustness of the findings.

There were several limitations in the meta-analysis. Firstly, all of the current studies were taken from developed countries and there were missing data from developing countries or vulnerable populations. The current study is representative of developed countries, whereas the impact of antibiotics in children in vulnerable populations or developing countries may likely be different from that found in developed countries. Therefore, the impact between antibiotic exposure and childhood adiposity in developing countries or vulnerable populations is still unclear, and needs to be evaluated in future research. Secondly, there were obvious differences in those included studies. The confounding factors used in the adjusted estimates were different, which could result in heterogeneity and different outcomes (69). Thirdly, the use of antibiotics during follow-up may be an important factor modifying the impact of antibiotics on childhood adiposity risk. However, most included studies did not add antibiotics use during follow-up as a confounding factor, which might cause risk of bias. Fourthly, there were different types of antibiotics among included studies, and they might have different impact on childhood adiposity. Further studies are required to explore the impact of different types of antibiotics on childhood obesity. Finally, the relationship between antibiotic exposure and adiposity in adults has not been studied, and future research is recommended.

In summary, this meta-analysis provides strong evidence for the association between antibiotic exposure in early life and childhood adiposity. There is also an obvious dose-response relationship between antibiotic exposure and childhood adiposity. 
Prudent use of antibiotics is recommended for infants and children to reduce the risk of childhood adiposity. Future studies are also required to develop some effective methods to prevent obesity in infants or children exposing to antibiotics.

\section{AUTHOR CONTRIBUTIONS}

XS and JZ designed the study. XS, BW, XD, RS, and JZ contributed to the literature search, interpretation, writing, and

\section{REFERENCES}

1. Ng M, Fleming T, Robinson M, Thomson B, Graetz N, Margono C, et al. Global, regional, and national prevalence of overweight and obesity in children and adults during 1980-2013: a systematic analysis for the Global Burden of Disease Study 2013. Lancet (2014) 384(9945):766-81. doi:10.1016/ S0140-6736(14)60460-8

2. Cunningham SA, Kramer MR, Narayan KM. Incidence of childhood obesity in the United States. N Engl J Med (2014) 370(5):403-11. doi:10.1056/ NEJMoa1309753

3. Ogden CL, Carroll MD, Lawman HG, Fryar CD, Kruszon-Moran D, Kit BK, et al. Trends in obesity prevalence among children and adolescents in the United States, 1988-1994 through 2013-2014. JAMA (2016) 315(21):2292-9. doi:10.1001/jama.2016.6361

4. Simmonds M, Llewellyn A, Owen CG, Woolacott N. Predicting adult obesity from childhood obesity: a systematic review and meta-analysis. Obes Rev (2016) 17(2):95-107. doi:10.1111/obr.12334

5. Llewellyn A, Simmonds M, Owen CG, Woolacott N. Childhood obesity as a predictor of morbidity in adulthood: a systematic review and meta-analysis. Obes Rev (2016) 17(1):56-67. doi:10.1111/obr.12316

6. Sherman M. The relationship between obesity and depression in children and adolescents. Obes Rev (2016) 17(9):915-6. doi:10.1111/obr.12438

7. Munthali RJ, Kagura J, Lombard Z, Norris SA. Childhood adiposity trajectories are associated with late adolescent blood pressure: birth to twenty cohort. BMC Public Health (2016) 16:665. doi:10.1186/s12889-016-3337-x

8. Black MH, Zhou H, Takayanagi M, Jacobsen SJ, Koebnick C. Increased asthma risk and asthma-related health care complications associated with childhood obesity. Am J Epidemiol (2013) 178(7):1120-8. doi:10.1093/aje/ kwt093

9. Cote AT, Harris KC, Panagiotopoulos C, Sandor GG, Devlin AM. Childhood obesity and cardiovascular dysfunction. J Am Coll Cardiol (2013) 62(15):1309-19. doi:10.1016/j.jacc.2013.07.042

10. Skinner AC, Skelton JA. Prevalence and trends in obesity and severe obesity among children in the United States, 1999-2012. JAMA Pediatr (2014) 168(6):561-6. doi:10.1001/jamapediatrics.2014.21

11. Lemas DJ, Yee S, Cacho N, Miller D, Cardel M, Gurka M, et al. Exploring the contribution of maternal antibiotics and breastfeeding to development of the infant microbiome and pediatric obesity. Semin Fetal Neonatal Med (2016) 21:406-9. doi:10.1016/j.siny.2016.04.013

12. Yallapragada SG, Nash CB, Robinson DT. Early-life exposure to antibiotics, alterations in the intestinal microbiome, and risk of metabolic disease in children and adults. Pediatr Ann (2015) 44(11):e265-9. doi:10.3928/ 00904481-20151112-09

13. Mikkelsen KH, Allin KH, Knop FK. Effect of antibiotics on gut microbiota, glucose metabolism and body weight regulation: a review of the literature. Diabetes Obes Metab (2016) 18(5):444-53. doi:10.1111/dom.12637

14. Jess T. Microbiota, antibiotics, and obesity. N Engl J Med (2014) 371(26): 2526-8. doi:10.1056/NEJMcibr1409799

15. Keeney KM, Yurist-Doutsch S, Arrieta MC, Finlay BB. Effects of antibiotics on human microbiota and subsequent disease. Annu Rev Microbiol (2014) 68:217-35. doi:10.1146/annurev-micro-091313-103456

16. Principi N, Esposito S. Antibiotic administration and the development of obesity in children. Int J Antimicrob Agents (2016) 47(3):171-7. doi:10.1016/j. ijantimicag.2015.12.017

17. Ajslev TA, Andersen CS, Gamborg M, Sorensen TI, Jess T. Childhood overweight after establishment of the gut microbiota: the role of delivery mode, proofreading of the manuscript. XS, BW, LL, and QY extracted data and performed data analyses. XS, BW, and XA revised the study. XS and BW generated the figures.

\section{FUNDING}

The present work was supported by grants from the National Natural Science Foundation of China (No. 81670722 and 81471004).

pre-pregnancy weight and early administration of antibiotics. Int J Obes (Lond) (2011) 35(4):522-9. doi:10.1038/ijo.2011.27

18. Murphy R, Thompson JM, Mitchell EA. Early antibiotic exposure and body mass index in children born small for gestational age. Acta Paediatr (2013) 102(9):e434-5. doi:10.1111/apa.12307

19. Bailey LC, Forrest CB, Zhang P, Richards TM, Livshits A, DeRusso PA. Association of antibiotics in infancy with early childhood obesity. JAMA Pediatr (2014) 168(11):1063-9. doi:10.1001/jamapediatrics.2014.1539

20. Mueller NT, Whyatt R, Hoepner L, Oberfield S, Dominguez-Bello MG, Widen EM, et al. Prenatal exposure to antibiotics, cesarean section and risk of childhood obesity. Int J Obes (Lond) (2015) 39(4):665-70. doi:10.1038/ijo. 2014.180

21. Gerber JS, Bryan M, Ross RK, Daymont C, Parks EP, Localio AR, et al. Antibiotic exposure during the first 6 months of life and weight gain during childhood. JAMA (2016) 315(12):1258-65. doi:10.1001/jama. 2016.2395

22. Mbakwa CA, Scheres L, Penders J, Mommers M, Thijs C, Arts IC. Early life antibiotic exposure and weight development in children. J Pediatr (2016) 176:105-13.e2. doi:10.1016/j.jpeds.2016.06.015

23. Trasande L, Blustein J, Liu M, Corwin E, Cox LM, Blaser MJ. Infant antibiotic exposures and early-life body mass. Int J Obes (Lond) (2013) 37(1):16-23. doi:10.1038/ijo.2012.132

24. Azad M, Bridgman SL, Becker AB, Kozyrskyj AL. Infant antibiotic exposure and the development of childhood overweight and central adiposity. Int J Obes (Lond) (2014) 38(10):1290-8. doi:10.1038/ijo.2014.119

25. Wells G, Shea B, O'connell D, Peterson J, Welch V, Losos M, et al. The Newcastle-Ottawa Scale (NOS) for Assessing the Quality of Nonrandomised Studies in Meta-Analyses. Ottawa: Ottawa Health Research Institute (2015). Available from: http://www.ohri.ca/programs/clinical_epidemiology/oxford. asp

26. Cochran WG. The combination of estimates from different experiments. Biometrics (1954) 10(1):101-29. doi:10.2307/3001666

27. Higgins JP, Thompson SG, Deeks JJ, Altman DG. Measuring inconsistency in meta-analyses. BMJ (2003) 327(7414):557-60. doi:10.1136/ bmj.327.7414.557

28. DerSimonian R, Laird N. Meta-analysis in clinical trials. Control Clin Trials (1986) 7(3):177-88. doi:10.1016/0197-2456(86)90046-2

29. Li DK, Chen H, Ferber J, Odouli R. Infection and antibiotic use in infancy and risk of childhood obesity: a longitudinal birth cohort study. Lancet Diabetes Endocrinol (2016) 5:18-25. doi:10.1016/S2213-8587(16)30281-9

30. Egger M, Davey Smith G, Schneider M, Minder C. Bias in meta-analysis detected by a simple, graphical test. BMJ (1997) 315(7109):629-34. doi:10.1136/bmj.315.7109.629

31. Orsini N, Bellocco R, Greenland S. Generalized least squares for trend estimation of summarized dose-response data. Stata J (2006) 6(1):40-57.

32. Orsini N, Li R, Wolk A, Khudyakov P, Spiegelman D. Meta-analysis for linear and nonlinear dose-response relations: examples, an evaluation of approximations, and software. Am J Epidemiol (2012) 175(1):66-73. doi:10.1093/aje/ kwr265

33. Halldorsson T, Rytter D, Haug LS, Bech BH, Danielsen I, Becher G, et al. Prenatal exposure to perfluorooctanoate and risk of overweight at 20 years of age: a prospective cohort study. Environ Health Perspect (2012) 120(5):668-73. doi:10.1289/ehp.1104034

34. Trehan I, Goldbach HS, LaGrone LN, Meuli GJ, Wang RJ, Maleta KM, et al. Antibiotics as part of the management of severe acute malnutrition. $N$ Engl J Med (2013) 368(5):425-35. doi:10.1056/NEJMoa1202851 
35. Vidal AC, Murphy SK, Murtha AP, Schildkraut JM, Soubry A, Huang Z, et al. Associations between antibiotic exposure during pregnancy, birth weight and aberrant methylation at imprinted genes among offspring. Int J Obes (Lond) (2013) 37(7):907-13. doi:10.1038/ijo.2013.47

36. Angelakis E, Million M, Kankoe S, Lagier JC, Armougom F, Giorgi R, et al. Abnormal weight gain and gut microbiota modifications are side effects of long-term doxycycline and hydroxychloroquine treatment. Antimicrob Agents Chemother (2014) 58(6):3342-7. doi:10.1128/AAC.02437-14

37. Murphy R, Stewart AW, Braithwaite I, Beasley R, Hancox RJ, Mitchell EA, et al. Antibiotic treatment during infancy and increased body mass index in boys: an international cross-sectional study. Int J Obes (Lond) (2014) 38(8):1115-9. doi:10.1038/ijo.2013.218

38. Krenz-Niedbala M, Koscinski K, Puch EA, Zelent A, Breborowicz A. Is the relationship between breastfeeding and childhood risk of asthma and obesity mediated by infant antibiotic treatment? Breastfeed Med (2015) 10(6):326-33. doi:10.1089/bfm.2014.0173

39. Mor A, Antonsen S, Kahlert J, Holsteen V, Jorgensen S, Holm-Pedersen J, et al. Prenatal exposure to systemic antibacterials and overweight and obesity in Danish schoolchildren: a prevalence study. Int J Obes (Lond) (2015) 39(10):1450-5. doi:10.1038/ijo.2015.129

40. Rogawski ET, Westreich DJ, Adair LS, Becker-Dreps S, Sandler RS, Sarkar R, et al. Early life antibiotic exposure is not associated with growth in young children of Vellore, India. J Pediatr (2015) 167(5):1096-2.e3. doi:10.1016/j. jpeds.2015.08.015

41. Saari A, Virta LJ, Sankilampi U, Dunkel L, Saxen H. Antibiotic exposure in infancy and risk of being overweight in the first 24 months of life. Pediatrics (2015) 135(4):617-26. doi:10.1542/peds.2014-3407

42. Korpela K, Salonen A, Virta LJ, Kekkonen RA, de Vos WM. Association of early-life antibiotic use and protective effects of breastfeeding: role of the intestinal microbiota. JAMA Pediatr (2016) 170(8):750-7. doi:10.1001/ jamapediatrics.2016.0585

43. Korpela K, Salonen A, Virta LJ, Kekkonen RA, Forslund K, Bork P, et al. Intestinal microbiome is related to lifetime antibiotic use in Finnish preschool children. Nat Commun (2016) 7:10410. doi:10.1038/ncomms10410

44. Schwartz BS, Pollak J, Bailey-Davis L, Hirsch AG, Cosgrove SE, Nau C, et al. Antibiotic use and childhood body mass index trajectory. Int J Obes (Lond) (2016) 40(4):615-21. doi:10.1038/ijo.2015.218

45. Scott FI, Horton DB, Mamtani R, Haynes K, Goldberg DS, Lee DY, et al. Administration of antibiotics to children before age 2 years increases risk for childhood obesity. Gastroenterology (2016) 151(1):120-9.e5. doi:10.1053/j. gastro.2016.03.006

46. Wang H, Wang N, Wang B, Fang H, Fu C, Tang C, et al. Antibiotics detected in urines and adipogenesis in school children. Environ Int (2016) 89-90:204-11. doi:10.1016/j.envint.2016.02.005

47. Reijnders D, Goossens GH, Hermes GD, Neis EP, van der Beek CM, Most J, et al. Effects of gut microbiota manipulation by antibiotics on host metabolism in obese humans: a randomized double-blind placebo-controlled trial. Cell Metab (2016) 24(1):63-74. doi:10.1016/j.cmet.2016.06.016

48. Ville A, Heyman MB, Medrano R, Wojcicki JM. Early antibiotic exposure and risk of childhood obesity in Latinos. Child Obes (2017) 13:231-5. doi: 10.1089/chi.2016.0235

49. Poulsen M, Pollak J, Bailey-Davis L, Hirsch AG, Glass TA, Schwartz BS. Associations of prenatal and childhood antibiotic use with child body mass index at age 3 years. Obesity (Silver Spring) (2017) 25(2):438-44. doi:10.1002/ oby. 21719

50. Manco M, Putignani L, Bottazzo GF. Gut microbiota, lipopolysaccharides, and innate immunity in the pathogenesis of obesity and cardiovascular risk. Endocr Rev (2010) 31(6):817-44. doi:10.1210/er.2009-0030

51. Guyenet SJ, Schwartz MW. Clinical review: regulation of food intake, energy balance, and body fat mass: implications for the pathogenesis and treatment of obesity. JClin Endocrinol Metab (2012) 97(3):745-55. doi:10.1210/jc. 2011-2525

52. Ridaura VK, Faith JJ, Rey FE, Cheng J, Duncan AE, Kau AL, et al. Gut microbiota from twins discordant for obesity modulate metabolism in mice. Science (2013) 341(6150):1241214. doi:10.1126/science.1241214

53. Winer DA, Luck H, Tsai S, Winer S. The intestinal immune system in obesity and insulin resistance. Cell Metab (2016) 23(3):413-26. doi:10.1016/j. cmet.2016.01.003
54. Ussar S, Griffin NW, Bezy O, Fujisaka S, Vienberg S, Softic S, et al. Interactions between gut microbiota, host genetics and diet modulate the predisposition to obesity and metabolic syndrome. Cell Metab (2015) 22(3):516-30. doi:10.1016/j.cmet.2015.07.007

55. Hersoug LG, Moller P, Loft S. Gut microbiota-derived lipopolysaccharide uptake and trafficking to adipose tissue: implications for inflammation and obesity. Obes Rev (2016) 17(4):297-312. doi:10.1111/obr.12370

56. Rosenbaum M, Knight R, Leibel RL. The gut microbiota in human energy homeostasis and obesity. Trends Endocrinol Metab (2015) 26(9):493-501. doi:10.1016/j.tem.2015.07.002

57. Pihl AF, Fonvig CE, Stjernholm T, Hansen T, Pedersen O, Holm JC. The role of the gut microbiota in childhood obesity. Child Obes (2016) 12(4):292-9. doi:10.1089/chi.2015.0220

58. Nicolucci AC, Hume MP, Martinez I, Mayengbam S, Walter J, Reimer RA. Prebiotic reduces body fat and alters intestinal microbiota in children with overweight or obesity. Gastroenterology (2017). doi:10.1053/j.gastro.2017. 05.055

59. Angelakis E, Merhej V, Raoult D. Related actions of probiotics and antibiotics on gut microbiota and weight modification. Lancet Infect Dis (2013) 13(10):889-99. doi:10.1016/S1473-3099(13)70179-8

60. Mahana D, Trent CM, Kurtz ZD, Bokulich NA, Battaglia T, Chung J, et al. Antibiotic perturbation of the murine gut microbiome enhances the adiposity, insulin resistance, and liver disease associated with high-fat diet. Genome Med (2016) 8(1):48. doi:10.1186/s13073-016-0297-9

61. Hwang I, Park YJ, Kim YR, Kim YN, Ka S, Lee HY, et al. Alteration of gut microbiota by vancomycin and bacitracin improves insulin resistance via glucagon-like peptide 1 in diet-induced obesity. FASEB J (2015) 29(6): 2397-411. doi:10.1096/fj.14-265983

62. Cho I, Yamanishi S, Cox L, Methe BA, Zavadil J, Li K, et al. Antibiotics in early life alter the murine colonic microbiome and adiposity. Nature (2012) 488(7413):621-6. doi:10.1038/nature11400

63. Uijtdewilligen L, Waters CN, Muller-Riemenschneider F, Lim YW. Preventing childhood obesity in Asia: an overview of intervention programmes. Obes Rev (2016) 17:1103-15. doi:10.1111/obr.12435

64. Nishtar S, Gluckman P, Armstrong T. Ending childhood obesity: a time for action. Lancet (2016) 387(10021):825-7. doi:10.1016/S0140-6736(16) 00140-9

65. Cauchi D, Glonti K, Petticrew M, Knai C. Environmental components of childhood obesity prevention interventions: an overview of systematic reviews. Obes Rev (2016) 17:1116-30. doi:10.1111/obr.12441

66. Barker CI, Standing JF, Turner MA, McElnay JC, Sharland M. Antibiotic dosing in children in Europe: can we grade the evidence from pharmacokinetic/pharmacodynamic studies-and when is enough data enough? Curr Opin Infect Dis (2012) 25(3):235-42. doi:10.1097/QCO.0b013e328 $353105 \mathrm{c}$

67. Kaliannan K, Wang B, Li XY, Bhan AK, Kang JX. Omega-3 fatty acids prevent early-life antibiotic exposure-induced gut microbiota dysbiosis and later-life obesity. Int J Obes (Lond) (2016) 40(6):1039-42. doi:10.1038/ ijo. 2016.27

68. Economopoulos KP, Ward NL, Phillips CD, Teshager A, Patel P, Mohamed MM, et al. Prevention of antibiotic-associated metabolic syndrome in mice by intestinal alkaline phosphatase. Diabetes Obes Metab (2016) 18(5):519-27. doi:10.1111/dom.12645

69. Forrest CB, Block JP, Bailey LC. Antibiotics, infections, and childhood obesity. Lancet Diabetes Endocrinol (2016) 5:2-3. doi:10.1016/S2213-8587(16) 30314-X

Conflict of Interest Statement: The authors declare that the research was conducted in the absence of any commercial or financial relationships that could be construed as a potential conflict of interest.

Copyright (c) 2017 Shao, Ding, Wang, Li, An, Yao, Song and Zhang. This is an open-access article distributed under the terms of the Creative Commons Attribution License (CC BY). The use, distribution or reproduction in other forums is permitted, provided the original author(s) or licensor are credited and that the original publication in this journal is cited, in accordance with accepted academic practice. No use, distribution or reproduction is permitted which does not comply with these terms. 